\section{Leishmaniose tegumentar americana: caracterização clínica, evolutiva, laboratorial e epidemiológica (Belo Horizonte, 1989-95)}

\begin{abstract}
A partir de 1987, a leishmaniose tegumentar americana (LTA) se instala e se torna endêmica na Região Metropolitana de Belo Horizonte (RMBH), Estado de Minas Gerais (MG). De 01/02/1989 a 31/12/95 foi realizado estudo prospectivo concorrente com a participação de 388 pacientes com LTA em ambulatório referência do Centro de Pesquisas René Rachou da Fundação Oswaldo Cruz. Os seguintes aspectos foram considerados: 1) descrição das características epidemiológicas, clínicas e laboratoriais dos pacientes; 2 ) determinação dos fatores associados à presença da leishmaniose mucosa (LM), à presença de lesões múltiplas na leishmaniose cutânea (LC) e à presença da forma disseminada da LC e 3) investigação dos fatores prognósticos da recidiva até dois anos após tratamento com antimonial. Após consentimento informado, os pacientes responderam a um protocolo pré-definido, foram examinados e tratados. A inclusão no estudo considerou o aspecto da lesão somado à positividade de pelo menos um dos exames laboratoriais: 1) intradermorreação de Montenegro (IDRM) e/ou 2) reação de imunofluorescência indireta (RIFI) (IgG anti-Leishmania) e/ou 3) pesquisa direta do parasito. Foram incluídos 254 homens e 134 mulheres, com idade entre seis meses e 80 anos. Destes, 264 pacientes $(68,0 \%)$ residiam na $\mathrm{RMBH}, 117$ (30,1\%) residiam em outros municípios de MG e sete $(1,9 \%)$ em outros estados do Brasil. A LC ocorreu em 358 $(93,5 \%)$ e a LM em $25(6,5 \%)$ pacientes. Cinco pacientes apresentaram a forma disseminada (LCD). Os pacientes com LM diferiam dos com LC nos seguintes aspectos: maior tempo de doença $\left(\chi_{1}^{2}=41,15, p<0,01\right)$, maior freqüência de doença simultânea (Razão de chance $(\mathrm{RC})=$ 3,77 , Intervalo de confiança (IC) $=1,16-11,16$ ) e menor freqüência de relato de tratamento inespecífico anterior $(R C=0,34, I C=0,14-0,82$ ). Estes dados sugerem que a debilitação pela idade e doenças simultâneas podem contribuir
\end{abstract}

\section{American cutaneous leishmaniasis: clinical, prospective, laboratory and epidemiological evaluation (Belo Horizonte, Minas Gerais State, Brazil, 1989-95)}

American cutaneous leishmaniasis (ACL) has been detected in the Metropolitan Region of Belo Horizonte (MRBH), State of Minas Gerais, since 1987. From 1989 to 1995, 388 patients with ACL were followed-up at the outpatient clinic of the René Rachou Research Center, Oswaldo Cruz Foundation, Belo Horizonte, Minas Gerais State. The objectives of the present study were: 1 ) to describe the social, epidemiological, clinical and laboratory characteristics of the patients, 2) to determine the factors associated with the presence of mucocutaneous leishmaniasis (ML), the form with multiple lesions and disseminated of cutaneous leishmaniasis (CL), and 3 ) to investigate the predictors of recurrence of $A C L$, up to two years after antimonial treatment. A written informed consent was obtained from all patients. The patients then answered a predifined protocol, were examined and treated. A patient was only included in the cohort if he had a suggestive lesion, and was positive to at least one of the following tests: Montenegro skin test (MST), indirect immunofluorescence test (IFT), or direct finding of the parasite. The final cohort comprised 254 men and 134 women, with the age ranging from six months to 80 years. Two hundred and sixty four patients $(68.0 \%)$ were residents of the MRBH, 117 (30.1\%) were from other cities of the same State and seven $(1.9 \%)$ from other States of Brazil. Clinical presentation was $\mathrm{CL}$ in 358 (93.5\%) patients and $\mathrm{ML}$ in 25 (6.5\%). Five patients presented the disseminated cutaneous form (DCL). Patients with ML differed from those with $\mathrm{CL}$ in the following aspects: longer time of disease evolution $\left(\chi_{1}{ }^{2}=41.15\right.$, $\mathrm{p}<0.01$ ), history of concomitant diseases (OR $=3.77, \mathrm{Cl}=1.16-11.16)$ and a lower frequency of reported previous nonspecific treatment (OR $=0.34, \mathrm{Cl}=0.14-0.82)$. These data suggest that duration of disease and concomitant infections might contribute to activation and/or mucous dissemination of Leishmania. It is not possible to 
para a ativação e/ou disseminação mucosa de Leishmania. Como a análise foi seccional, não há como definir se estes fatores foram causa ou conseqüência da LM. A menor freqüência de tratamento inespecífico anterior nos pacientes com LM poderia ser devido ao menor acesso a recursos médicos ou a viés de memória. As únicas diferenças encontradas entre os aspectos dos 106 pacientes com lesões múltiplas e os 252 com lesão única da LC foram a história familiar positiva para $\mathrm{LTA}(\mathrm{RC}=1,85, \mathrm{IC}=1,21$ $2,83)$ e a menor freqüência de relato de tratamento inespecífico anterior $(R C=0,57$, $\mathrm{IC}=0,37-0,86$ ). Essas associações sugerem que os pacientes com lesões múltiplas residiam em focos mais ativos da LTAe que teriam tido menor acesso ao tratamento. Nenhum dos cinco pacientes com LCD era soropositivo para HIV1/2. Quando comparados aos 383 pacientes com outras formas de LTA, verificou-se que os pacientes com LCD apresentavam menor escolaridade $(p=0,047)$, maior incidência de alcoolismo $(R C=100,0, I C=4,97-1633,9)$ e maior freqüência de recidivas pós-tratamento $(R C=11,58, I C=1,10-122,1)$. Apesar do pequeno número de casos, estes resultados apontam para a influência de piores condições clínicas no desenvolvimento da LCD. A sensibilidade da IDRM foi $77,6 \%$ para LC, $88 \%$ para LM e $80 \%$ para LCD. A sensibilidade da RIFI foi $78,3 \%$ para LC, $95,2 \%$ para LM e $100 \%$ para LCD. A pesquisa direta foi positiva em 95/139 $(68,3 \%)$ pacientes. A sensibilidade diminuiu $(p<0,05)$ de $78,6 \%$ nas lesões recentes $(\leq 3 \mathrm{~m}$ ) para $63,6 \%$ nas antigas $(\geq 12 \mathrm{~m})$. Os resultados dos exames foram comparados e apresentaram taxas negativas de concordância (Índice Kappa $<1,0$ ). Apesquisa direta foi mais sensível quanto menor o tempo da lesão, enquanto a IDRM e a RIFI tenderam a apresentar maior sensibilidade com o aumento do tempo da lesão. Estes dados sugerem diminuição da sensibilidade do exame parasitológico e aumento da sensibilidade dos exames que refletem respostas imune com o evoluir da infecção. Acomparação das respostas de 335 soros de LTA com a sorologia (RIFI, ELISAe HAI) para doença de Chagas (DC) com antígeno bruto de Trypanosoma cruzie o ELISA com antígeno recombinante (rTc24) mostrou um grande percentual (12-46\%) de reações positivas com a sorologia convencional (RIFI, ELISAe HAI) para DC e apenas $6,7 \%$ com o rTc24; sugerindo maior especificidade do rTc24 no diagnóstico da DC. A amplificação do DNA pela reação em cadeia da polimerase e hibridização com sondas moleculares permitiu a caracterização define in a cross-sectional analysis whether these factors preceded or followed ML. The lower frequency of nonspecific treatment of ML patients might indicate reduced access to medical and therapeutic resources or a recall bias. The only differences found between the 106 patients with multiple lesions and the 252 patients with a single lesion of $C L$ were a higher frequency of positive family history of $\mathrm{ACL}(\mathrm{OR}=1.85, \mathrm{Cl}=1.21-2.83)$ and a lower frequency of reported previous nonspecific treatment $(\mathrm{OR}=0.57, \mathrm{Cl}=0.37-0.86)$. These data suggest that patients with multiple lesions might come from more active foci of ACL and that they also tend to have less access to treatment. None of the DLC cases was seropositive for HIV-1/2. Compared to the other forms of $A C L, D C L$ patients were of lower educational level $(p=0.047)$, had a more frequent history of alcoholism $(\mathrm{OR}=100.00, \mathrm{Cl}=4.97$ 1633.9) and a higher rate of recurrence posttreatment $(\mathrm{OR}=11.58, \mathrm{Cl}=1.10-122.1)$. Although based only on 5 cases, there was a relashionship between the worse clinical condition of the patiets and the development of DCL. The sensitivity of the MST was $77.6 \%$ for CL, $88 \%$ for $\mathrm{ML}$ and $80 \%$ for $\mathrm{DCL}$. The sensitivity of the IFT was $78.3 \%$ for CL, $95.2 \%$ for $\mathrm{ML}$ and $100 \%$ for DCL. The direct finding of parasites in biopsy smears was positive in $95 / 139(68.3 \%)$ of cases. Sensitivity was $63.6 \%$ for old lesions ( $\geq 12 \mathrm{mo}$.) and $78.6 \%$ for recent lesions $(\leq 3 \mathrm{mo}$.). The results of parasite detection, IFT and MST were compared and presented negative rates of agreement (Kappa < 1), suggesting that parasitologic sensitivity decreases as the immune response increases. Three hundred and thirtyfive patients with ACL submitted to serology (IFT, ELISA and IHA) for Chagas' disease showed high positivity (12-46\%) when using a crude Trypanosoma cruzi extract and low positivity $(6.7 \%)$ when using a recombinant antigen (rTc24), reflecting a greater specificity of rTc24. Parasite DNA amplification by the polymerase chain reaction (PCR) and further hybridization with molecular probes allowed the caracterization of Leishmania subgenus from 46 clinical specimens and 12 isolates in culture. Leishmania Viannia was typed from 52 cases and L. Leishmania was typed from 4 cases. Eleven out of the 12 PCR-typed culture isolates were previously characterized by isoenzyme profile: 8 isolates were typed as $L$. ( $V$.) braziliensis and 3 as $L$.(L.) amazonensis. The agreement between the PCR-typed subgenus and the L.(V.) braziliensis isoenzyme-typed species, together with clinical 
do subgênero do parasito de 46 tecidos e 12 isolados de cultura. Leishmania Viannia foi identificado em 52 e L. Leishmania em 4 casos. Onze amostras foram também caracterizadas por eletroforese de isoenzimas: oito $(72,7 \%)$ como L. (V.) braziliensis, e três $(27,3 \%)$ como $L$ (L.) amazonensis. Acorrelação total entre as amostras caracterizadas como L. Viannia por PCR e hibridização e $L$. $(V$.) braziliensis por eletroforese de isoenzimas, associada a evidências clínicas e epidemiológicas, sugerem a L.(V.) braziliensis como a espécie predominante na região. O tratamento foi realizado com antimoniato de meglumina, $15 \mathrm{mg} \mathrm{Sbv/Kg/dia} \mathrm{para} \mathrm{LC} \mathrm{e} 20 \mathrm{mg}$ $\mathrm{Sbv} / \mathrm{Kg} /$ dia para LM, em ciclos de dez dias, por no mínimo dois ciclos para LC e três ciclos para LM. Apenas seis pacientes se trataram por tempo inferior ao preconizado, mas apresentaram cicatrização completa das lesões e nenhuma recidiva durante o período estudado. $O$ tratamento apresentou alta eficácia primária: 94,8\% e 5,2\% dos pacientes apresentavam cicatrização total das lesões logo ao término ou em até 30 dias após tratamento, respectivamente. Os efeitos colaterais foram freqüentes: artralgia $(10,2 \%)$, náuseas $(9,2 \%)$, mialgia $(5,5 \%)$ e "rash" cutâneo $(3,4 \%)$; mas não implicaram em interrupção do tratamento. Não foram observadas arritmias cardíacas ou morte súbita. A recidiva ocorreu em $32 / 318$ casos. O risco acumulado para a ocorrência de recidiva após tratamento em dois anos de observação foi igual a 10,5\%: 26 (81,3\%) recidivas ocorreram em até seis meses e 30 $(93,8 \%)$ em até um ano após tratamento, reforçando a recomendação de controle por até um ano pós-tratamento. Trinta dos 32 casos de recidiva ocorreram em pacientes com LC tratados com $15 \mathrm{mg} \mathrm{Sbv} / \mathrm{Kg} /$ dia, sugerindo a necessidade do uso da dose de $20 \mathrm{mg} \mathrm{Sbv/Kg/dia} \mathrm{também}$ para os casos de LC por L. (V.) braziliensis. A IDRM negativa esteve associada a um risco três vezes maior de recidiva após tratamento $(R R=3,44, I C-1,70-6,99)$. Este resultado sugere que a IDRM, além de ser um ferramenta sensível e especifica no diagnóstico da LTA, pode ser também utilizada na avaliação prognóstica, selecionando os pacientes com maior risco de recidiva, mesmo após o tratamento correto. and epidemiological evidences, indicates $L$. (V.) braziliensis as the dominant species in this study. All patients were treated with meglumine antimoniate, CL patients were given $15 \mathrm{mg}$ $\mathrm{Sb} v / \mathrm{kg} /$ day and MLpatients $20 \mathrm{mg} \mathrm{Sbv/kg} /$ day for 10 days, repeated after an interval of ten days for at least two times for CL and three times for ML. Six patients did not complete treatment, but in all cases the lesions were healed and no reccurrences occurred. Antimonial treatment presented high primary efficacy: $94.8 \%$ and $5.2 \%$ of patients present a scarred cured lesion at the end or up to 30 days after the end of treatment, respectively. Side effects were frequent: arthralgia $(10.2 \%)$, nausea $(9.2 \%)$, myalgia $(5.5 \%)$ and skin rash $(3.4 \%)$, but none led to interruption of treatment. No cardiac arrhythmia or sudden death was observed. There were 32/318 recurrences of ACL. The accumulated risk of recurrence in the two years following treatment was $10.5 \%: 26$ $(81.3 \%)$ recurrences occurred within six months and $30(93.8 \%)$ within 12 months after the end of treatment, reinforcing the need of controlling for recurrences after treatment for at least one year. Thirty of the 32 cases of disease recurrence were CL patients, treated with $15 \mathrm{mg} \mathrm{Sbvkg/day}$ of meglumine antimoniate. It might be desirable to increase the dose used for CL cases of $L(V)$ braziliensis to $20 \mathrm{mg} \mathrm{Sbv} / \mathrm{kg} /$ day. A negative response to MST before treatment was associated with a threefold increase in the risk of recurrence of $\mathrm{ACL}$ after treatment $(\mathrm{RR}=3,44 ; \mathrm{Cl}-1,70-6,99)$. This result suggests that the response to MST, already used as a sensitive and specific diagnostic tool, can also be useful as a prognostic test to select patients at greater risk of disease recurrence after treatment.

Valéria Maria de Azeredo Passos

Tese apresentada à Faculdade de Medicina da

Universidade Federal de Minas Gerais para

obtenção do Título de Doutor.

Belo Horizonte, MG, Brasil, 1998. 